\title{
The impact of hillslope groundwater dynamics and landscape functioning in event-flow generation: a field study in the Rietholzbach catchment, Switzerland
}

\author{
Jana von Freyberg • P. Suresh C. Rao • Dirk Radny • \\ Mario Schirmer
}

\begin{abstract}
A reliable prediction of hydrograph responses in mountainous headwater catchments requires a mechanistic understanding of the coupled hydro-climatic processes in these regions. This study shows that only a small fraction of the total area in a pre-Alpine headwater catchment actively regulates streamflow responses to hydro-climatic forcing, which facilitates the application of a parsimonious framework for hydrograph time-series prediction. Based on landscape analysis and hydrometric data from the Upper Rietholzbach catchment (URHB, $0.94 \mathrm{~km}^{2}$, northeast Switzerland), a conceptual model was established. Here, the rainfall-event-driven contribution of surface runoff and subsurface flow (event flow) accounts for around $50 \%$ of total river discharge. The event-flow hydrograph is generated from approximately $25 \%$ of the entire area consisting of riparian zones $(8 \%)$ and adjacent hillslopes $(17 \%)$, each with characteristic streamflowgenerating mechanisms. Baseflow generation is attributed to deep groundwater discharge from a fractured-rock aquifer covering $\sim 75 \%$ of the catchment area. A
\end{abstract}

Received: 20 June 2014 / Accepted: 10 February 2015

Published online: 26 March 2015

(C) Springer-Verlag Berlin Heidelberg 2015

Electronic supplementary material The online version of this article (doi:10.1007/s10040-015-1238-1) contains supplementary material, which is available to authorized users.

\section{J. Freyberg $(\bullet)$}

Department of Environmental Systems Science,

Swiss Federal Institute of Technology Zürich, 8092, Zurich, Switzerland

e-mail: jana.vonfreyberg@usys.ethz.ch

J. Freyberg $\cdot$ D. Radny $\cdot$ M. Schirmer

Department of Water Resources and Drinking Water,

Eawag Swiss Federal Institute of Aquatic Science and Technology, 8600, Dübendorf, Switzerland

J. Freyberg $\cdot$ M. Schirmer

Centre for Hydrogeology and Geothermics (CHYN),

University of Neuchâtel, 2000, Neuchâtel, Switzerland

P. S. C. Rao

Lyles School of Civil Engineering \& Agronomy Department, Purdue University, West Lafayette, IN 47907-2051, USA minimalistic model, that represents event flow as depletion of two parallel linear reservoirs, verified the conceptual model of the URHB with adequate hydrograph simulations $\left(R^{2}=0.67\right.$, Nash-Sutcliffe efficiency (NSE) $\left.=0.64\right)$. Hereby, the expansion of the event-flow contributing areas was found to be particularly significant during long and high-intensity rainfall events. These findings provide a generalized approach for the large-scale characterization of groundwater recharge and hydrological behavior of mountainous catchments with similar landscape properties.

Keywords Groundwater recharge/water budget . Minimalistic model · Mountainous catchments · Switzerland · Rainfall/runoff

\section{Introduction}

In many regions of the world, small headwater catchments in mountainous regions are one of the most important sources of freshwater (Viviroli et al. 2003). A sustainable management of these freshwater resources requires an integrated understanding of the dominant physical feedback mechanisms between the various components of the hydrologic cycle, however, adequate hydrological modeling of these regions remains a challenging task (Blöschl 2011). This is because mountainous headwater catchments, including the preAlpine catchment studied here, are often characterized by steep slopes, thin soil cover and high intensity precipitation that lead to flashy discharge responses and strong variability of streamflow. Further, their hydrology is controlled by the complex interaction of dynamic climatic processes (e.g., rainfall, radiation, evapotranspiration) and landscape properties (e.g., soil types, vegetation, topography) at various temporal and spatial scales.

The discretization of catchments into functionally homogeneous landscape units with characteristic streamflow-generation processes provides an integrative approach that combines the preferences of lumped and fully distributed hydrological models (e.g., Basu et al. 2010; Beven and Kirkby 1979; Sivapalan 2003). It is assumed that the landscape acts as a hydrologic filter, integrating the coupled dynamic hydro-climatic processes at the local 
scale into the observed catchment-specific responses (e.g., Carey et al. 2010; Gall 2013; Thompson et al. 2011). Small-scale landscape properties and physical processes can then be described by macroscopic-effective parameters, for instance soil porosity, water-table depth, storage capacity or vegetation cover, in order to enhance modeling efficiency (e.g., Basu et al. 2010; Botter et al. 2007; Ghasemizade and Schirmer 2013).

Following McGlynn and Seibert (2003), riparian zones and hillslopes can be considered the most basic landscape units since they distinctly differ in their hydrological, biogeochemical and topographic properties. Spatiotemporal variability of these hydrologically active landscape units (e.g., Beven and Kirkby 1979; Seibert and McGlynn 2005), which often is triggered by soil moisture thresholds, rainfall intensities and heterogeneous subsurface properties (e.g., Ali et al. 2013; Penna et al. 2011; Zehe and Sivapalan 2009), can cause nonlinear hydrological catchment behavior. Moreover, the hydrologic connectivity among the contributing landscape units, and their connectivity to the river network, both define the probability distribution of groundwater residence times and alters the overall hydrologic catchment response (e.g., Gupta et al. 1980; Kirchner 2003; Rinaldo et al. 2011; Tetzlaff et al. 2007). Numerous studies have focused on the experimental analysis of the spatiotemporal variability of hydrologically active landscape units with respect to streamflow generation (e.g., Dahlke et al. 2009; Graham et al. 2010; James and Roulet 2009) and solute export (e.g., Doppler et al. 2012; Gburek et al. 2002; Woodbury et al. 2014).

The delineation of hydrological landscape units can be based solely on the physical surface and subsurface features of a catchment such as topography, soil types, geology and vegetation cover (e.g., Beven and Kirkby 1979; Gharari et al. 2011; Gupta et al. 1980; McGlynn and Seibert 2003). Additionally, water-table variations in unconfined aquifers can serve as valuable proxies for dominant flow processes, for instance by analyzing typical time scales for infiltration and groundwater discharge (e.g., Lyon et al. 2006; McGlynn et al. 2004).

The present study analyzes the role of the two hydrological landscape units, riparian zones and adjacent hillslopes, for event-scale streamflow generation in a mountainous headwater catchment. Here, event flow is defined as the rainfall-event-driven contributions of surface runoff and subsurface flow to streamflow (i.e., corrected for baseflow), which is the most variable hydrograph component. In this context, the following research questions were addressed: How can the dominant streamflow-generating hydrological landscape units in the catchment be differentiated? How do landscape structure and subsurface properties control the dominant flow processes and event-flow generation? How is event-flow generation affected by spatiotemporal variability of the contributing areas? To answer these research questions an integrative approach was pursued, which combines digital-elevation-model-based terrain analysis, experimentally derived subsurface properties, hydrometric measurements and a parsimonious modeling framework at a small preAlpine headwater catchment in northeast Switzerland.
This paper first identifies important flow processes at the hillslope scale and the catchment scale to delineate the hydrologic landscape units and to develop an conceptual model. The conceptual description of the catchment is then evaluated with a minimalistic, threshold-based hydrologic model that assumes event-flow generation from two linear reservoirs (hillslope and riparian zone). In the last section of this paper, the role of variable contributing areas (VCA) for event-flow hydrograph simulations is systematically assessed, and major limitations of the applied framework and concluding remarks are presented.

\section{Site description}

The Upper Rietholzbach sub-catchment (URHB, $0.94 \mathrm{~km}^{2}$ ) is a pre-Alpine headwater catchment located in the headwaters of the Swiss Thur River basin $\left(1,750 \mathrm{~km}^{2}\right.$, Fig. 1). It comprises the western part of the Rietholzbach catchment (RHB, $3.14 \mathrm{~km}^{2}$ ), which has been the subject of various hydro-meteorological studies since the late 1970s (e.g., Germann 1981; Gurtz et al. 2003b; Koenig et al. 1994; Teuling et al. 2010; Vitvar and Balderer 1997; von Freyberg et al. 2014) because its hydroclimatology is representative of the larger region of the Swiss northeastern pre-Alps (Seneviratne et al. 2012). The local climate is characterized by temperate humid conditions with high rainfall rates in late spring and summer (MeteoSchweiz 2013). Average annual sums of precipitation and evapotranspiration are around 1,450 and $560 \mathrm{~mm}$, respectively (based on data from 1976-2006, Ewen et al. 2011).

Elevations in the URHB range from 744 to 910 masl. Around $72 \%$ of the land surface is used as pastureland, $19 \%$ is forested, $4 \%$ is settlement or streets and $5 \%$ is covered by a wetland in the western central part of the catchment. The geology is composed of the Tertiary Upper Freshwater Molasse (UFM) that forms steep slopes and plateaus at higher elevations. The UFM consists of differentially permeable geologic strata such as consolidated clastic sediments, marl, sandstone and limestone, resulting in a large variability of hydraulic conductivities (1.7E-6-1.1E-4 m s s , Balderer, 1983).

Pleistocene glacial moraine deposits (GMD) overlay the UFM in the valley bottom (Fig. S1 of the electronic supplementary material (ESM). The GMD is characterized by a heterogeneous composition of unconsolidated conglomerates and Quaternary gravel pockets (Balderer 1980). Hydraulic conductivities of the GMD-aquifer material were estimated by measuring the recovery rates of hydraulic head in several piezometers after a nearly instantaneous withdrawal of a groundwater volume (Bouwer and Rice 1976). At the upper hillslope (piezometer locations P1, P2 and P3, Fig. 1c) hydraulic conductivities range between $8 \mathrm{E}-6$ and $1 \mathrm{E}-4 \mathrm{~m} \mathrm{~s}^{-1}$ and become smaller towards the valley bottom with values between $1 \mathrm{E}-6$ and $3 \mathrm{E}-6 \mathrm{~m} \mathrm{~s}^{-1}$ (piezometer locations P5, P6 and P10, Fig. 1c). Effective porosity in the GMD ranges from 0.05 to 0.1 , as obtained from pumping tests in a 

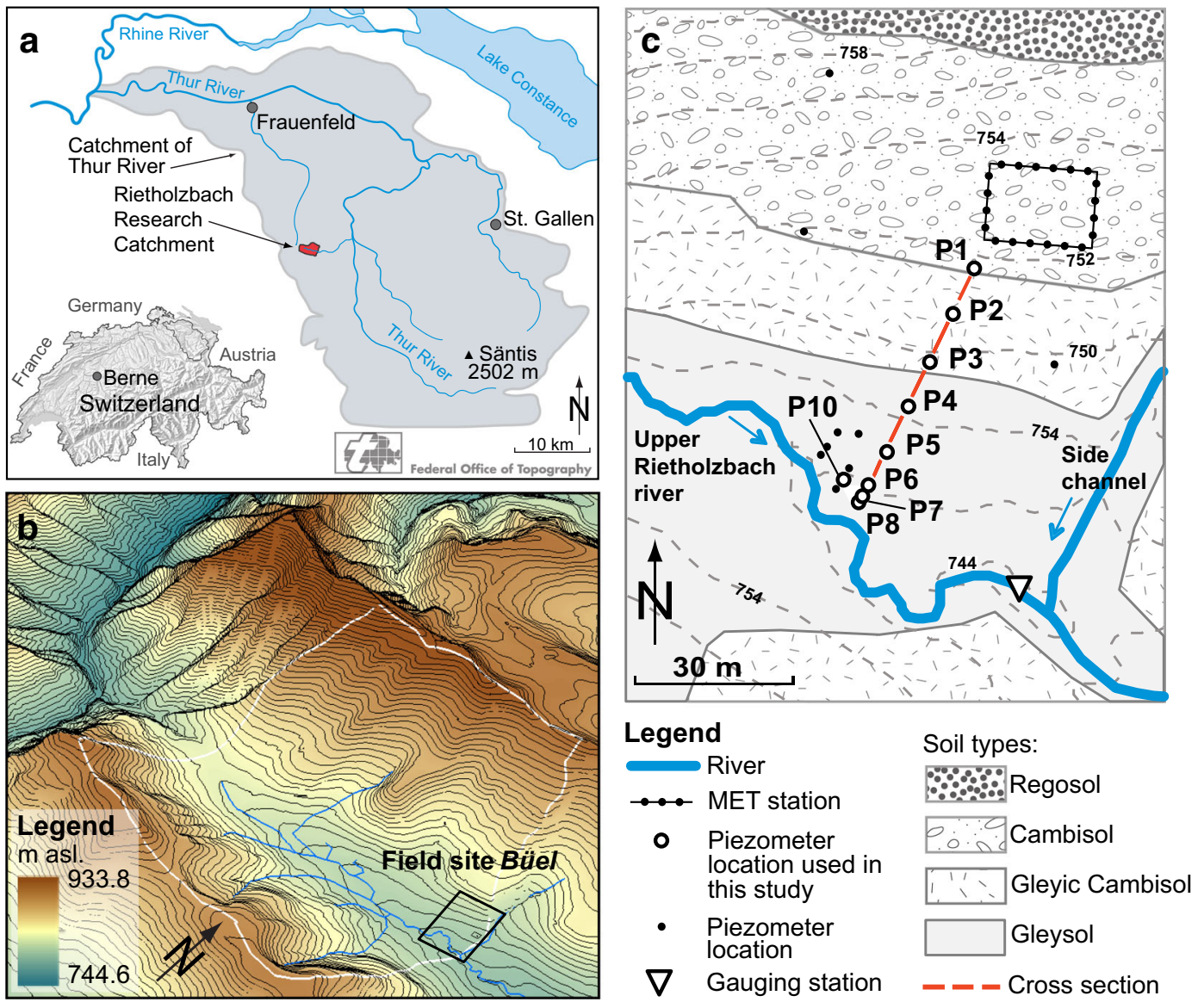

Fig. 1 a Location of the Rietholzbach catchment $(R H B)$ as part of the Thur basin in NE Switzerland; b Boundary of the Upper Rietholzbach sub-catchment (URHB; white line) as the western part of the RHB and location of the Büel site (black square); c Büel site with observation network and main soil types-modified after H. Kuhn, Swiss Federal Institute of Technology (ETH), Zurich, unpublished report "Bodenkartierung HYDREX" ("Soil Map HYDREX"), 1980 - the side channel joins the URHB-river downstream of the gauging station

neighboring catchment (Balderer 1984; Vitvar and Balderer 1997).

Soil core sampling and electrical resistivity tomography surveys revealed a several-meters thick confining clay- and silt layer between GMD and UFM (von Freyberg et al. 2014). No groundwater was found beneath this layer, suggesting that the GMD forms a perched aquifer, which is hydrologically disconnected from the UFMaquifer. The dominant soil types in the URHB are Regosols on the UFM, and Cambisols on the lower slopes of the GMD. Gelysols and peatysoils can be found at the flat valley bottom areas (Fig. 1c, Fig. S1 of the ESM). The soil texture of the Cambisol is gravelly loam to clay loam with increasing clay contents towards the valley bottom (Mittelbach et al. 2012). According to Germann (1981), soil depths range from less than $50 \mathrm{~cm}$ (Regosols) to up to $2 \mathrm{~m}$ (Cambisols).

\section{Methods}

\section{Monitoring and data processing}

Near the catchment outlet, the URHB is equipped with 2 -inch piezometers for monitoring water-table

Hydrogeology Journal (2015) 23: 935-948 responses at the hillslope-scale (Büel site, Fig. 1c). Eight piezometers were installed in summer 2011 by direct push technology $\left(G^{-e o p r o b e}{ }^{\circledR}\right.$ ) along a 50-m transect with the dimensions given in Table 1 . In seven piezometers of the transect, water-table variations were recorded at 15-min intervals with data loggers (SensorTechnik Sirnach, DL/N 70 , accuracy $1 \mathrm{~cm}$ ). During the study period, piezometer P7 served as the location for other experimental studies and, therefore, was not equipped with a data logger. The depth of the water table below the soil surface, $z_{\mathrm{gw}}(\mathrm{L})$, is denoted with positive values (Fig. 2). The position of the deepest water table recorded within the study period is represented by $z_{\min }(\mathrm{L})$ and the depth of the confining clay and silt layer from the ground surface is $z_{\text {conf }}(\mathrm{L})$. Terms are summarized in the Appendix.

Because of the large measurement biases of up to $60 \%$ for solid precipitation in the URHB (Gurtz et al. 2003a), this study solely considers the snow-free periods from 1 March to 31 October in 2011 and 2012. Time series of water-table depths are available for the periods 1 July to 31 October 2011 and 1 March to 31 October 2012. Data gaps of up to $6 \mathrm{~h}$ were filled by linear interpolation. Longer periods of missing water-table data are listed in Table 1. 
Table 1 Properties of the piezometers installed at the Büel site in the URHB. The top edges of all piezometer pipes are between 8 and $22 \mathrm{~cm}$ below the ground surface (bgs)

\begin{tabular}{|c|c|c|c|c|c|c|}
\hline Piezometer & $\begin{array}{l}\text { Topographic } \\
\text { height of top edge } \\
\text { (m asl) }\end{array}$ & $\begin{array}{l}\text { Installation } \\
\text { depth (m bgs) }\end{array}$ & $\begin{array}{l}\text { Depth of } \\
\text { filter section } \\
(\mathrm{m} \mathrm{bgs})\end{array}$ & $\begin{array}{l}\text { Depth to confining } \\
\text { layer (m bgs) }\end{array}$ & $\begin{array}{l}\text { Distance to the } \\
\text { river bank }(m)\end{array}$ & $\begin{array}{l}\text { Data gaps due } \\
\text { to logger failure } \\
(\mathrm{dd} / \mathrm{mm} / \mathrm{yy})\end{array}$ \\
\hline P1 & 751.64 & 5.2 & $1.2-4.2$ & 5 & 53.3 & - \\
\hline $\mathrm{P} 2$ & 750.63 & 5.2 & $1.2-4.2$ & 4.4 & 43.3 & $10 / 9 / 11-31 / 10 / 11$ \\
\hline P3 & 749.75 & 4.2 & $1.2-3.2$ & 3.8 & 33.3 & - \\
\hline P4 & 748.28 & 3.1 & $1.1-2.1$ & 2.4 & 23.3 & $6 / 9 / 12-30 / 10 / 12$ \\
\hline P5 & 746.56 & 3.1 & $1.1-2.1$ & $1.9^{\mathrm{a}}$ & 13.3 & $10 / 5 / 12-4 / 6 / 12$ \\
\hline P6 & 745.83 & 3 & $1.0-2.0$ & $1.6^{\mathrm{a}}$ & 6 & $\begin{array}{l}1 / 7 / 11-26 / 7 / 11 \\
6 / 9 / 12-30 / 10 / 12\end{array}$ \\
\hline P7 & 745.59 & 3 & $1.0-2.0$ & 1.5 & 4 & - \\
\hline P8 & 745.46 & 2.7 & $0.7-1.7$ & 1.5 & 2.9 & $1 / 7 / 11-25 / 8 / 11$ \\
\hline
\end{tabular}

${ }^{a}$ No soil core was obtained. Depth was linearly interpolated from nearby measurements

At a meteorological station (MET) near the catchment outlet rainfall was recorded every $15 \mathrm{~min}$ with a heated tipping bucket positioned $1.5 \mathrm{~m}$ above the ground (measurement error 3-15\%). Hourly sums of vertical percolation and actual evapotranspiration were obtained directly by mass-balance calculations from a weighting lysimeter $(2.5 \mathrm{~m}$ deep and $2.0 \mathrm{~m}$ in diameter, measurement error $0.032 \mathrm{~mm}$ ) following the post-processing procedure described in Jaun (2003). River discharge was monitored continuously every $15 \mathrm{~min}$ at the outlet of the URHB (Ott Hydrometrie AG, ODS4, measurement error up to $15 \%$ ). More information about the experimental set-up of the URHB can be found in Seneviratne et al. (2012) and von Freyberg et al. (2014).

\section{A minimalistic threshold-based model for the simulation of groundwater dynamics and event flow}

To develop a simplistic yet robust method for the simulation of event-streamflow generation in the URHB, a parsimonious modeling approach is employed that consists of two parallel and linear reservoirs (Fig. 2). The reservoirs represent the hydrological landscape units (hillslope and riparian zone), and differ in terms of their subsurface properties which, in turn, define the dominant flow processes. In the hillslope reservoir, infiltrating rainwater is assumed to percolate vertically to the groundwater body and then as lateral matrix flow towards the river, resulting in a delayed and dampened groundwater discharge signal. For the riparian zone reservoir, it is simply assumed that shallow subsurface stormflow and surface runoff is generated immediately when rainfall occurs.

The minimalistic model utilizes the linear soil-water balance model of Rodriguez-Iturbe et al. (1999) to account for the competition between infiltration and evapotranspiration in the upper soil profiles of the two reservoirs. The storage capacity of this active soil layer is defined by its depth $\left(z_{\mathrm{r}}(\mathrm{L})\right.$, typically the average rooting depth) and the maxumum soil moisture content (or soil porosity). The daily soil-water deficit, $\theta_{\text {def }}(t)(-)$, is the difference between the values of antecedent soil moisture, $\theta_{\mathrm{i}}(t)(-)$, and maximum soil moisture, $\theta^{*}(-)$, which is typically between field capacity and full saturation. It is further assumed that the soil-water content never falls below the wilting point $\theta_{\mathrm{w}}$. The temporal evolution of relative soil-water content, $\theta(t)(-)$, in the active soil layer is controlled by infiltration from rainfall, losses are due to evapotranspiration and deep percolation beyond $z_{\mathrm{r}}$. The compensation of the daily soil-water deficit, $\theta_{\operatorname{def}}(t)(-)$, in the active soil layer triggers the occurrence of instantaneous deep percolation, i.e. simulated groundwater recharge, $R^{\prime}(t)\left(\mathrm{L} \mathrm{T}^{-1}\right)$. Accordingly, the water balance equation within the upper soil layer of a reservoir reads:

$R^{\prime}(t)=P(t)-\mathrm{ET}(t)-z_{\mathrm{r}} \cdot \theta_{\text {def }}(t)$

where $P(t)\left(\mathrm{L} \mathrm{T}^{-1}\right)$ is rainfall, $\operatorname{ET}(t)\left(\mathrm{L} \mathrm{T}^{-1}\right)$ is actual evapotranspiration and $\theta_{\operatorname{def}}(t)(-)$ is the soil-water storage deficit at time $t$. Positive values of $R^{\prime}(t)$ are defined here as simulated groundwater recharge with $R^{\prime}(t)=0$ when the right hand term of Eq. (1) becomes negative. A change of the unit-area groundwater volume $\left(\frac{d V_{\mathrm{gw}}^{\prime}(t, x)}{d t}\left(\mathrm{LT}^{-1}\right)\right)$ is presumed to depend linearly on recharge that is modulated by the effective porosity of the aquifer material $\varphi(-)$ :

$\frac{d V_{\mathrm{gw}}{ }^{\prime}(t, x)}{d t}=\frac{R^{\prime}(t)}{\varphi}$

Groundwater discharge is described with an exponential function to represent the recession behavior of the groundwater storage (e.g., Beven 2001; Brutsaert 2005):

$f(t)=c \cdot k_{\mathrm{gw}} \cdot \exp \left(-k_{\mathrm{gw}} \cdot t\right)$

In Eq. (3), $c$ is a scaling constant to satisfy $\int f(t)=1$ and $k_{\mathrm{gw}}$ is the inverse of the mean residence time of groundwater. The parameter $k_{\mathrm{gw}}$ can be estimated with the master recession curve separation tool of Posavec et al. (2010). The fully automated method fits sets of daily water-table recession curves that span at least 4 days to an overall exponential regression function. Unit-area groundwater discharge flux, $D^{\prime}(t)\left(\mathrm{L} \mathrm{T}^{-1}\right)$ can then be simulated by convolution of the predicted recharge pulses $\left(R^{\prime}(t)\right)$ and the instantaneous unit hydrograph function, $f(t)$ : 


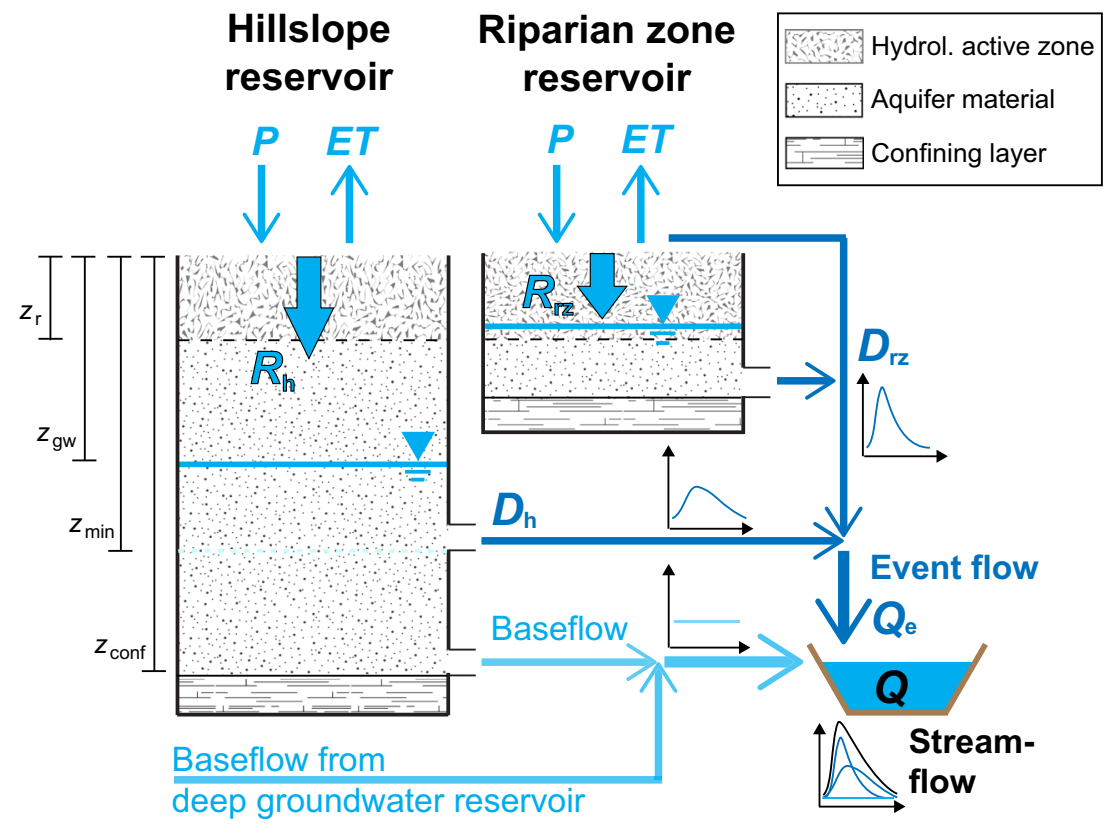

Fig. 2 Schematic description of the minimalistic modeling concept consisting of two parallel event-flow-generating linear reservoirs (hillslope, riparian zone) and a baseflow reservoir. The following model parameters are presented: $z_{r}$ root zone depth; $z_{g w}$ depth to the water table; $z_{\text {min }}$ depth to the deepest water table; $z_{\text {conf }}$ depth to the confining layer; $P$ precipitation; ET actual evapotranspiration; $R_{h}$ and $R_{r z}$ groundwater recharge of the hillslope and riparian zone, respectively; $D_{h}$ and $D_{r z}$ groundwater discharge of the hillslope and riparian zone, respectively; $Q_{e}$ event flow; $Q$ total river streamflow

$D^{\prime}(t)=\int_{0}^{t} R^{\prime}(t) f(t-\tau) d \tau$

For the hillslope reservoir, it is assumed that the infiltration of rainfall occurs instantaneously at the daily timescale, which makes the infiltration rate equal to the rainfall rate. Since an entirely rainfall-driven response of hillslope water tables shall be simulated with this model, lateral influx of groundwater from other catchment areas is considered to be constant and can, therefore, be neglected (Fig. 2).

For the riparian zone reservoir is assumed that $\theta_{\text {def }}$ is zero to simulate a direct runoff signal when rainfall occurs. Thus, Eq. (1) simplifies to $R^{\prime}(t)=P(t)-\mathrm{ET}(t)$ and $k_{\mathrm{gw}}=1 \mathrm{~d}^{-1}$, which corresponds to a mean groundwater residence time of 1 day.

Total simulated event flow, $Q_{\mathrm{e}}{ }^{\prime}(t)\left(\mathrm{L} \mathrm{T}^{-1}\right)$, is the sum of hillslope and riparian zone discharge $\left(D_{\mathrm{h}}{ }^{\prime}(t), D_{\mathrm{rz}}{ }^{\prime}(t)\right)$ from the areal portions, $A_{\mathrm{h}}, A_{\mathrm{rz}}(-)$, multiplied by $\alpha(-)$, which is the quotient of event-flow index (or 1 - baseflow index) and the portion of event-flow generating area $\left(A_{\mathrm{e}}=A_{\mathrm{h}}+A_{\mathrm{rz}}\right)$ :

$Q_{\mathrm{e}}^{\prime}(t)=\alpha \cdot\left(A_{\mathrm{h}} \cdot D_{\mathrm{h}}^{\prime}(t)+A_{\mathrm{rz}} \cdot D_{\mathrm{rz}}^{\prime}(t)\right)$

\section{Estimation of hillslope groundwater recharge and discharge}

To allow a robust evaluation of the minimalistic modeling concept, hillslope groundwater volumes, $V_{\mathrm{gw}}(x, t)\left(\mathrm{L}^{3} \mathrm{~T}^{-1}\right)$, were estimated from water table observations:

Hydrogeology Journal (2015) 23: 935-948
$V_{\mathrm{gw}}(x, t)=l \cdot \varphi \cdot \int_{x=d_{1}}^{d_{2}} \int_{\tau=0}^{\tau=t}\left(z_{\mathrm{conf}}-z_{\mathrm{gw}}(x, \tau)\right) d x d \tau$

where $l(\mathrm{~L})$ denotes the width of the hillslope section, $d_{1}$ (L) and $d_{2}(\mathrm{~L})$ mark its beginning and end perpendicular to and $z_{\mathrm{conf}}-z_{\mathrm{gw}}(\mathrm{L})$ is the saturated thickness of the aquifer above the confining layer (Fig. 2). In order to consider only groundwater recharge and discharge relevant for event-flow generation, the observed depth to water table $\left(z_{\mathrm{gw}}\right)$ in Eq. (6) is corrected for the deepest water table recorded $\left(z_{\min }\right)$. It is assumed that leakage into the confining layer is negligible and that the composition of the aquifer is isotropic and homogeneous with an effective porosity $\varphi(-)$

Daily fluxes of hillslope groundwater recharge, $R_{\mathrm{h}}(t)$ $\left(\mathrm{L}^{3} \mathrm{~T}^{-1}\right)$, and discharge, $D_{\mathrm{h}}(t)\left(\mathrm{L}^{3} \mathrm{~T}^{-1}\right)$, at the Büel site can then be estimated by the increase or decrease of groundwater volume over a time period ( $\Delta t=1$ day), respectively:

$\frac{V_{\mathrm{gw}}(x, t+\Delta t)-V_{\mathrm{gw}}(x, t)}{\Delta t}=\left\{\begin{array}{l}>0 \Leftrightarrow R_{\mathrm{h}}(x, t) \\ <0 \Leftrightarrow D_{\mathrm{h}}(x, t)\end{array}\right.$

\section{Results and discussion}

\section{Dominant flow processes and delineation of hydrological landscape units}

The areal portions of the hillslope and riparian zone reservoirs are important model input parameters that 
depend on the hydrologic surface and subsurface properties of the catchment. Thus, streamflow time series and water table dynamics of the URHB were studied in detail and correlated to distinct landscape features (also see sections 2 and 3 of the ESM).

Analysis of the streamflow regime at the catchment scale Overall, the hydrological regime of the URHB follows a distinct non-linear storage-discharge relationship (Fig. S2 of the ESM), suggesting streamflow contributions from multiple storage reservoirs (Martina and Entekhabi 2006). Deep groundwater discharge (baseflow) shows only minor temporal variability and comprises around $50 \%$ of total annual streamflow (Fig. S3 of the ESM). Baseflowgeneration can be correlated to the substantial portion of Upper Freshwater Molasse (UFM) that underlies approximately $75 \%$ of the URHB area (Koenig et al. 1994; Vitvar and Balderer 1997). Since water tables are deep in the UFM aquifer with mean residence times of more than 1 year (Heidbüchel et al. 2012; Vitvar and Balderer 1997), the baseflow signal is strongly dampened and not directly affected by climatic forcing (e.g., rainfall, evapotranspiration; Koenig et al. 1994). This assumption is further supported by numerous perennial springs that originate from high-elevation regions of the URHB with underlying UFM.

The baseflow component of the hydrograph was estimated with the recursive digital filter technique after Nathan and McMahon (1990) by applying three passing times and a filter parameter of 0.95 to obtain a high degree of smoothing. Average baseflow indices of 0.5 from 1 March to 31 October 2011 and 0.6 from 1 March to 31 October 2012 were obtained, which are in good agreement with the long-term analysis (section 3 of the ESM) and, thus, can be considered representative for the long-term hydrological behavior of the URHB.

Streamflow rates above $2.8 \mathrm{~mm} \mathrm{~d}^{-1}$ (median flow) indicate a more dynamic hydrologic regime (Fig. S3 of the ESM), which is probably driven by rainfall events and the activation of quick groundwater fluxes and surface runoff. Source areas of this event-flow component of the hydrograph can therefore be in the more permeable regions of the landscape adjacent to the river network (i.e., the valley bottom areas underlain by unconsolidated Quaternary GMD) and on saturated or low-permeability soils, respectively (Koenig et al. 1994).

\section{Groundwater dynamics at the Büel site}

To identify dominant event-flow generating mechanisms in the GMD unit, the variability of water tables in 2011 and 2012 was analyzed with respect to the local surface- and subsurface properties at the Büel site. Figure 3 illustrates that the uppermost piezometer locations are characterized by deeper water tables $\left(z_{\mathrm{gw}}\right)$ and a larger saturated thickness $\left(z_{\text {conf }}-z_{\mathrm{gw}}\right)$ compared to the near-stream piezometers ( $\mathrm{P} 4, \mathrm{P} 5$, P6, P8). Steeper slopes of $z_{\mathrm{gw}_{\mathrm{w}}}$-distributions at low Hydrogeology Journal (2015) 23: 935-948 cumulative probabilities suggest rather dampened rainfall responses and a slow recession behavior of the water tables at the uphill piezometers (P1, P2, P3). Therefore, slow vertical percolation though the vadose zone and lateral flux through the saturated soil matrix are likely to be the dominant groundwater flow pathways.

The near-stream water tables showed a higher temporal variability, as is indicated by steeper slopes of the $z_{\mathrm{gw}^{-}}$and $\left(z_{\mathrm{conf}}-z_{\mathrm{gw}}\right)$-distributions in Fig. 3. Further, generally small $z_{\mathrm{gw}}$ values suggest the occurrence of full-saturation periods during rainfall events. At P5, the shallowest water tables $\left(z_{\mathrm{gw}}(P 5)<0.5 \mathrm{~m}\right)$ occurred $13 \%$ of the time (Fig. 3a). A similar behavior was found for P4, P6 and P8 for $z_{\mathrm{gw}}<0.75 \mathrm{~m}$; although, the water table did not reach the land surface. This indicates the existence of a hightransmissivity zone in the upper organic-rich soil layer that facilitates rapid lateral flux of shallow groundwater during rainfall (Dahlke et al. 2012; Lyon et al. 2006). Such high-transmissivity zones can be formed by root channels, animal burrows and partially buried logs (Bachmair and Weiler 2011).

In order to investigate such high-transmissivity zones in more detail, infiltration experiments were conducted with a double-ring infiltrometer at 11 plots across the Büel site between 24 June and 5 July 2013 (ASTM 2013; Philip 1957). Measured infiltration rates ranged from $0-2.6 \mathrm{E}-5 \mathrm{~m} \mathrm{~s}^{-1}$, with a distinct zone of low permeability at the flat bottom area of the Büel site that is underlain by Gleysol (infiltration rates 0 $6.7 \mathrm{E}-6 \mathrm{~m} \mathrm{~s}^{-1}$, arithmetic mean $3.7 \mathrm{E}-6 \mathrm{~m} \mathrm{~s}^{-1}, 5$ plots). The permeability of the soil increased towards further uphill areas. Near the MET, where Cambisol can be found, infiltration rates were between 1.0E-5 and 2.6E-5 m s ${ }^{-1}$ (arithmetic mean 1.8E$5 \mathrm{~m} \mathrm{~s}^{-1}, 6$ plots). This suggests that the storage deficit in the flat bottom area of the Büel site is very small, likely due to capillary rise from the shallow water table and low hydraulic permeability, that does not allow significant infiltration. Consequently, the absolute volume of groundwater recharge from percolating rainwater is presumably very small in this part of the Büel site. Instead, rainfall is likely to cause saturation excess, which triggers instantaneous overland flow and shallow subsurface stormflow in the uppermost soil layer (McGrath et al. 2007).

Accordingly, the Büel site can be discretized into the two hydrological landscape units: hillslope (uphill piezometers $\mathrm{P} 1, \mathrm{P} 2, \mathrm{P} 3$ ) and riparian zone (near-stream piezometers $\mathrm{P} 5, \mathrm{P} 6, \mathrm{P} 7, \mathrm{P} 8$ ) with piezometer $\mathrm{P} 4$ as the transition zone at a distance of $23.3 \mathrm{~m}$ from the riverbank. Similarly, the event-flow generating landscape units in the URHB are delineated as follows: relatively flat catchment areas (slopes $<7^{\circ}$ ) adjacent to the river network underlain by peaty soils and Gleysols are assigned riparian zones, whereas Cambisols overlying the GMD in the intermediate area of fractured-bedrock aquifer (UFM) and riparian zones are allocated to hillslopes. Thus, riparian zones and hillslopes cover approximately $7.5 \%\left(A_{\mathrm{rz}}\right)$ and $17.7 \%$ $\left(A_{\mathrm{h}}\right)$ of the URHB area, respectively. The remaining areal fraction of $74.8 \%$ accounts for strongly damped discharge of deep groundwater (baseflow), which does not contribute to event flow in the applied framework.

DOI $10.1007 / \mathrm{s} 10040-015-1238-1$ 

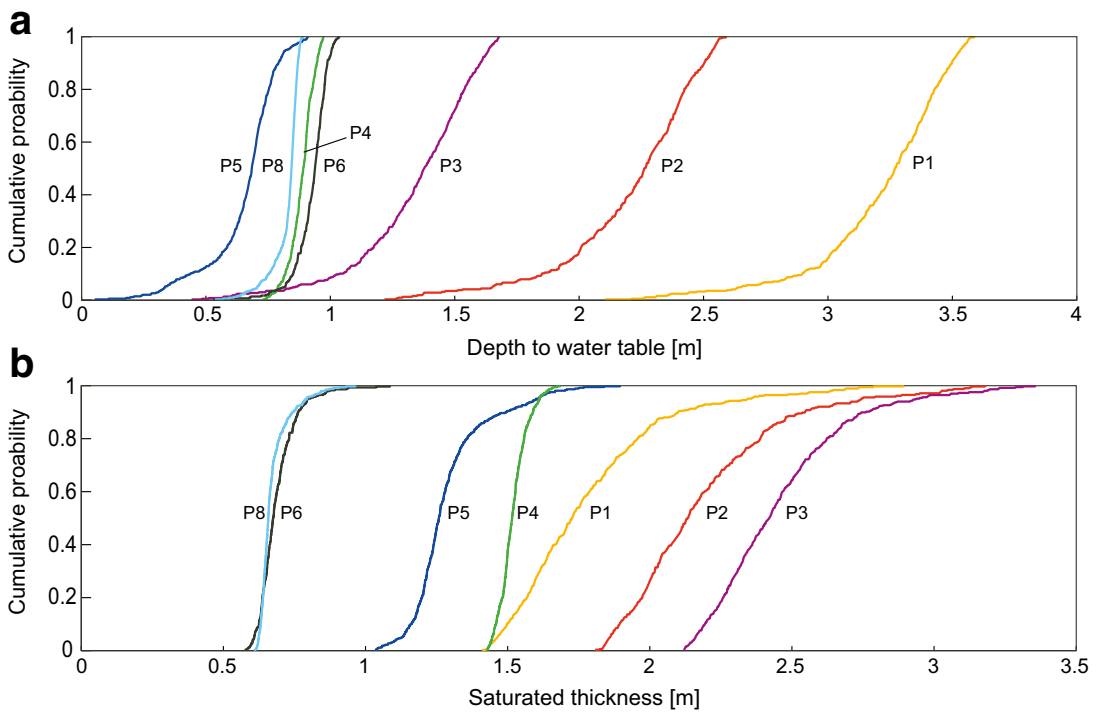

Fig. 3 Cumulative probabilities of daily water-table dynamics at piezometer locations $P 1-P 6$ and $P 8$ between 1 July and 31 October 2011 and between 1 March and 31 October 2012. a Depth to water table below the ground surface $\left(z_{\mathrm{gw}}\right)$; b saturated thickness above the confining layer $\left(z_{\mathrm{conf}}-z_{\mathrm{gw}}\right)$. Due to the shallow slope of the confining layer, $z_{\mathrm{conf}}-z_{\mathrm{gw}}$ was largest around the middle of the transect (P2, $\left.P 3\right)$ and not at the uppermost location $(P 1)$, where $z_{\text {conf }}-z_{\mathrm{gw}}$ was on average $0.6 \mathrm{~m}$ smaller

\section{Evaluation of groundwater-recharge and -discharge estimates at the hillslope scale}

To evaluate the representativeness of the hydrological landscape properties at the Büel site for the entire URHB, estimated hillslope groundwater volume $\left(V_{\mathrm{gw}}\right)$ and recharge $\left(R_{\mathrm{h}}\right)$ were compared to streamflow $(Q)$ and percolation measurements from the lysimeter. To accomplish this, Eq. (6) was applied with $d_{1}=23.3 \mathrm{~m}, d_{2}=53.3 \mathrm{~m}$ (hillslope section from P1 to P4), $l=1 \mathrm{~m}$ and $\varphi=0.075$ \pm 0.025 (Balderer 1980). Here, daily unit-area groundwater volume $\left(V_{\mathrm{gw}}\right)$ was calculated with respect to $z_{\min }$ to account solely for the event-flow generating portion of the hillslope groundwater storage (Fig. 2).

A significant linear correlation between $V_{\mathrm{gw}}$ and $Q$ was found for periods with $Q<2.8 \mathrm{~mm} \mathrm{~d}^{-1}\left(R^{2}=0.64\right.$, $p<0.0001$, grey shaded area in Fig. 4), indicating that hillslope groundwater is the dominant source of streamflow during low and median-flow conditions (Fig. S3 of the ESM). During high flow with $Q>2.8 \mathrm{~mm} \mathrm{~d}^{-1}$, the correlation becomes more scattered because most flood peaks occurred before the maximum hillslope groundwater volume was reached $\left(R^{2}=0.31\right.$, $p<0.0001$, non-shaded area in Fig. 4). Such extreme events can be attributed to non-stationary hydrological responses that were contingent on rainfall intensity and initial conditions of the streamflow contributing areas (e.g., local soil-water storage deficit).

Further, the method to estimate hillslope groundwater recharge and discharge is corroborated by a significant linear correlation between monthly sums of $R_{\mathrm{h}}$ and lysimeter seepage $\left(R^{2}=0.97, p<0.001\right.$; data points of March and August 2012 were excluded in the linear regression, see caption of Fig. 5). Slopes between 2.2 $(\varphi=0.05)$ and $1.3(\varphi=0.1)$ for the linear regression indicate an underestimation of $R_{\mathrm{h}}$ in relation to lysimeter seepage. This can be explained with the isolated soil column of the lysimeter that only allows vertical flow and prevents a hydraulic connection with the groundwater (Gurtz et al. 2003a). Thus, the open drainage collection system of the lysimeter base at $2.5 \mathrm{~m}$ depth allows quicker outflow of percolate compared to the surrounding undisturbed soil with a deeper zone of low-pressure head (e.g., median $z_{\mathrm{gw}}(\mathrm{P} 1)>3 \mathrm{~m}$; Healy and Scanlon 2010). Nevertheless, since the differences between $R_{\mathrm{h}}$ and lysimeter seepage are consistent, Eqs. (6) and (7) with $\varphi=0.1$ are considered applicable for providing a basis of comparison with the results of the minimalistic model.

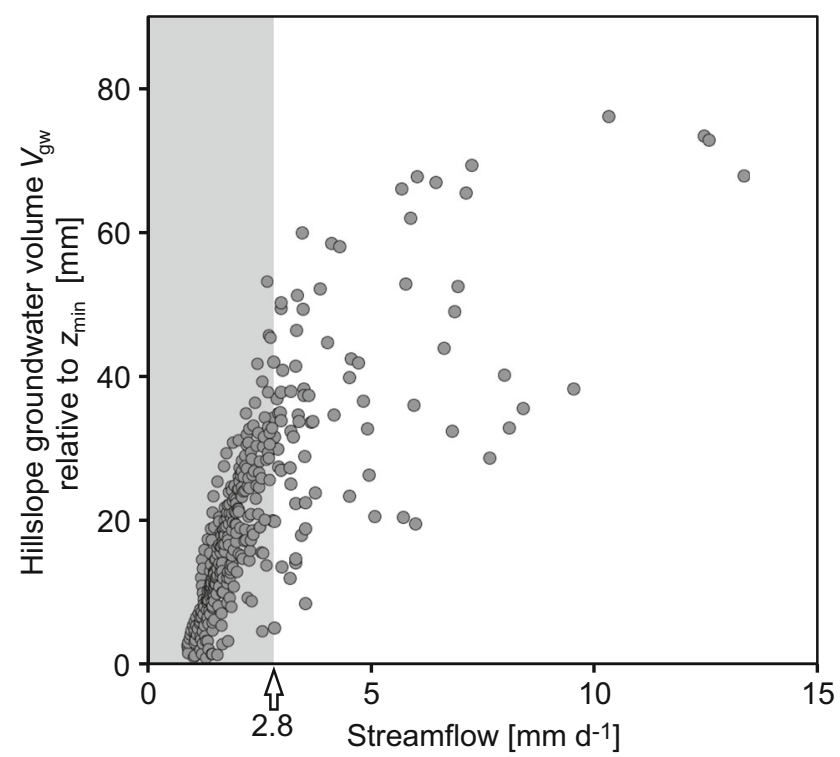

Fig. 4 Daily streamflow of the URHB ( $Q$, including baseflow) versus estimated hillslope groundwater volume $V_{\mathrm{gw}}$ relative to $z_{\mathrm{min}}$ $(\varphi=0.075)$ during 1 July-31 October 2011 and 1 March-31 October 2012 . The grey shaded area indicates flow conditions below median flow $\left(Q<2.8 \mathrm{~mm} \mathrm{~d}^{-1}\right)$. The ranges of flow conditions are the same for porosities of $\varphi=0.05$ and 0.1 , respectively 


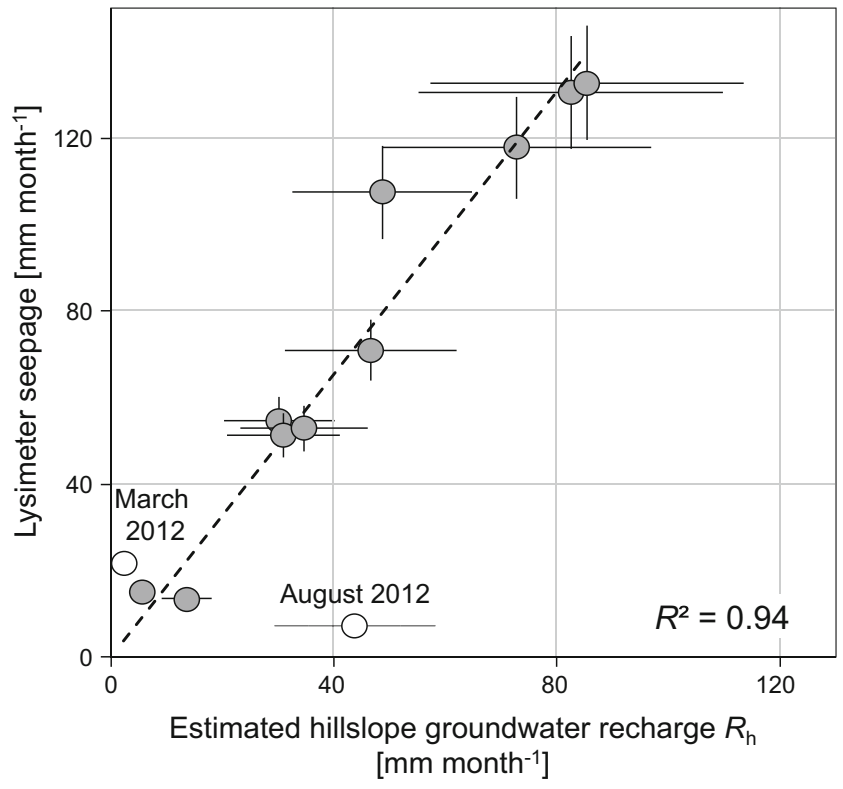

Fig. 5 Estimated monthly mean hillslope groundwater recharge during 1 July-31 October 2011 and 1 March-31 October 2012. Whiskers of groundwater recharge describe the range of values with effective porosities $(\varphi)$ between 0.05 and 0.1 and a $10 \%$ uncertainty of the lysimeter measurements (Seneviratne et al. 2012), respectively. The dashed line indicates the linear regression function with a slope of 1.62. The data point of March 2012 was excluded from the linear regression analysis due to logger failure at the lysimeter set-up. Further, the lysimeter seepage in August 2012 was considered unrepresentative since the physical properties of the weighting lysimeter led to an anomalous high soil moisture deficit in this month compared to the surrounding environment (Gurtz et al. 2003a). Due to the absence of a water table and the prevention of lateral groundwater flow into the lysimeter cylinder, a soil moisture deficit caused by evapotranspiration cannot be replenished by capillary rise and may persist over longer time periods. It is assumed that such a high soil moisture deficit developed in the lysimeter in July 2012, leading to very low seepage rates in August 2012 , where only $12 \%$ of the average seepage rate $\left(59 \mathrm{~mm} \mathrm{month}^{-1}\right)$ was measured

\section{Simulation of hillslope groundwater dynamics}

Hillslope groundwater dynamics were simulated with the minimalistic modeling approach by utilizing daily rainfall and actual evapotranspiration data from the MET and following site-specific input parameters: $z_{\mathrm{r}}=0.3 \mathrm{~m}$ (Germann 1981; Seneviratne et al. 2012), $\theta^{*}=0.34$ and $\theta_{\mathrm{w}}=0.17$ according to a clay loam (Dingman 2002). The effective porosity of the aquifer material $(\varphi)$ was set equal to 0.1 based on the preceding analysis. The hillslope reservoir was treated as a single hydrological unit with homogeneous subsurface properties and spatial uniform soil moisture deficit. The master recession curve separation tool of Posavec et al. (2010) was run with the estimated daily groundwater volume time series $\left(V_{\mathrm{gw}}\right)$ to obtain the parameter $k_{\mathrm{gw}}=0.09 \mathrm{~d}^{-1}$, which represents an average residence time of $1 / k_{\mathrm{gw}}=11 \mathrm{~d}$.

The hillslope reservoir model captured timing and amplitude for most of the recharge events, as indicated by the synchronous behavior of the cumulative sums of $R_{\mathrm{h}}$ and $R_{\mathrm{h}}{ }^{\prime}$ as well as $D_{\mathrm{h}}$ and $D_{\mathrm{h}}{ }^{\prime}$ (Fig. 6a, b). For both years, the simulated values are only slightly smaller than the estimates (2011: $\Sigma R_{\mathrm{h}}-\Sigma R_{\mathrm{h}}{ }^{\prime}=8.2 \mathrm{~mm}$, $\Sigma D_{\mathrm{h}}-\Sigma D_{\mathrm{h}}{ }^{\prime}=12.2 \mathrm{~mm}, 2012: \quad \Sigma R_{\mathrm{h}}-\Sigma R_{\mathrm{h}}{ }^{\prime}=5.7 \mathrm{~mm}$, $\left.\Sigma D_{\mathrm{h}}-\Sigma D_{\mathrm{h}}{ }^{\prime}=40.9 \mathrm{~mm}\right)$. Some recharge responses after dry periods were underpredicted by the model (e.g., October 2011, July to August 2012), suggesting that evapotranspiration losses entirely compensated incoming rainfall in the upper soil layer of the hillslope reservoir. Because the model does not account for capillary rise or groundwater influx from other reservoirs, soil moisture deficits are thus more persistent and simulated recharge is below the estimates.

Figure $6 \mathrm{c}$ and the evaluation of model performance with $R^{2}, p$-value, Nash-Sutcliffe efficiency (NSE) and percent bias $\left(P_{\text {bias }}\right)$ shows that the hillslope reservoir model represents the groundwater dynamics in the hillslope aquifer sufficiently $\left(R^{2}=0.78, p<0.001, P_{\text {bias }}=-34.0, \mathrm{NSE}=0.85\right)$. The general underprediction of $V_{\mathrm{gw}}{ }^{\prime}$ can be explained with the initial values in Eq. (1) used for each simulation year. Nevertheless, the minimalistic model is capable of reproducing rainfall responses and recession behavior of the observed water table, particularly during large rainfall events (e.g., July to August 2011 and April to July 2012).

\section{Simulation of event-flow hydrographs at the catchment scale}

The minimalistic hydrological model with two linear reservoirs (riparian zones and hillslopes) was applied to simulate the event-flow hydrograph $\left(Q_{\mathrm{e}}\right)$ of the URHB during the snow-free periods in 2011 and 2012. First, event-flow was simulated with the lowest degree of (spatial) complexity and thus with fixed areal portions of the hydrological landscape units (constant contributing areas, CCA) based on the findings in section "Dominant flow processes and delineation of hydrological landscape units". Second, the role of spatial variability of the landscape units on the hydrologic regime was assessed by implementing the variable contributing areas concept (VCA) into the minimalistic model.

\section{Constant contributing areas (CCA)}

The minimalistic model with CCA $\left(A_{\mathrm{rz}}=7.5 \%\right.$ and $A_{\mathrm{h}}=17.7 \%$ of $A_{\text {tot }}$, respectively) provides a good fit between the observed and simulated event hydrograph with $R^{2}=0.67, p<0.001, P_{\text {bias }}=6.2$ and $\mathrm{NSE}=0.64$ (first months of each simulation period were used as the initiation period and thus were excluded from this analysis, Fig. 7b). Despite the invariant riparian-zones area, the temporal variability of this event-flow component is simulated adequately, i.e. a large contribution at the beginning of rainfall events due to surface runoff and shallow subsurface stormflow. Hillslope groundwater discharge responds delayed, causing a slower recession of the event-flow hydrograph. However, large flood peaks $\left(Q_{\mathrm{e}^{>}}>3.5 \mathrm{~mm} \mathrm{~d}^{-1}\right)$ during short, highintensity rainfall events with more than $35 \mathrm{~mm}$ of rain were underpredicted by the minimalistic model and CCA (e.g., July 2011 and June 2011). The simulated 
a

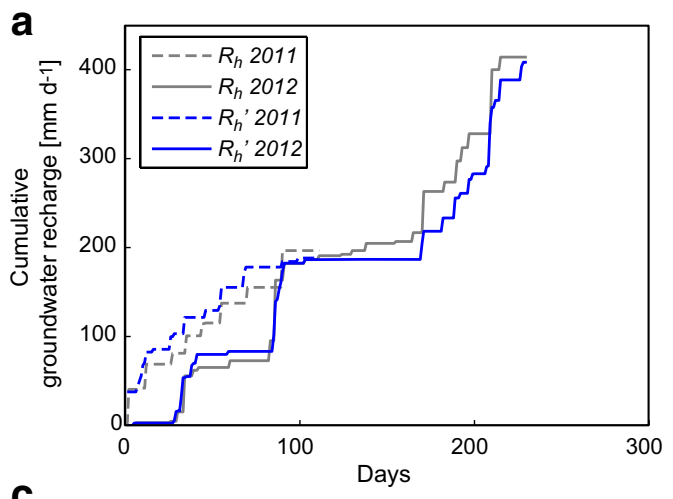

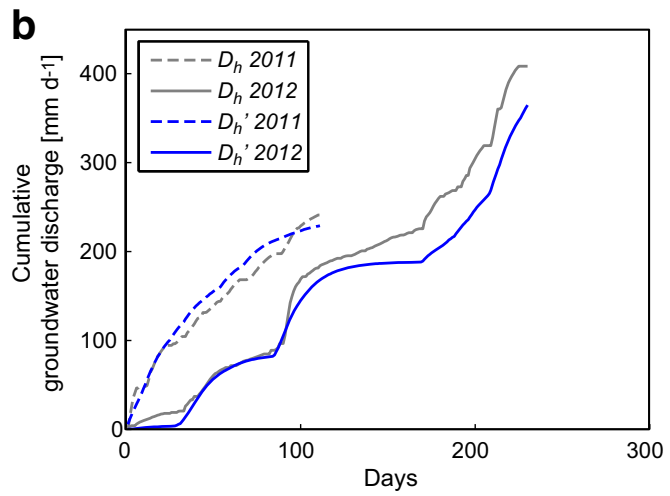

C

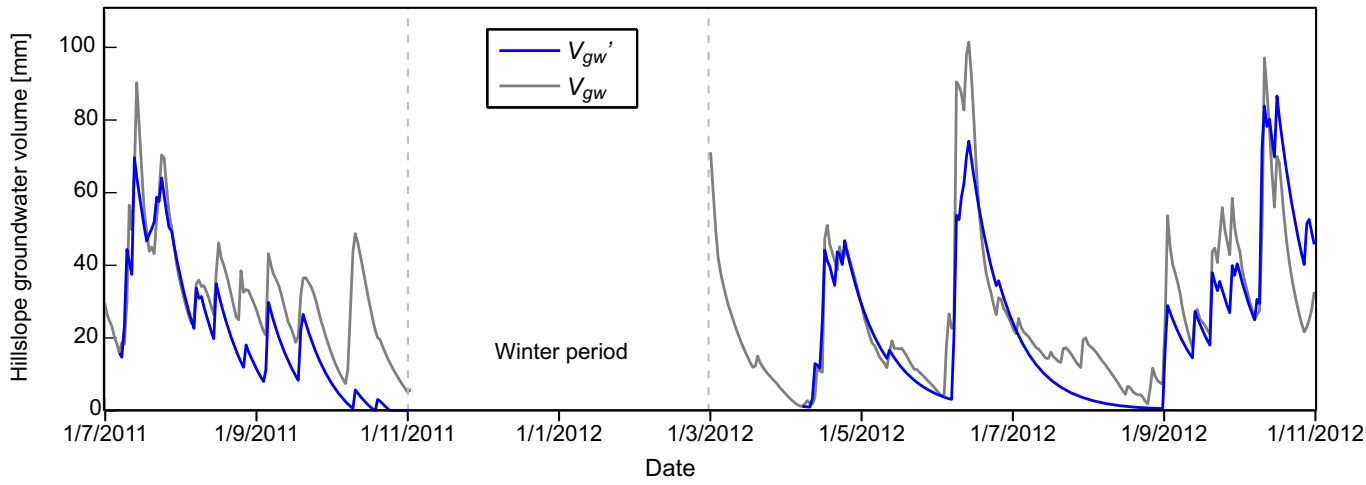

Fig. 6 Comparison of cumulative sums of a estimated $\left(R_{\mathrm{h}}\right.$, grey) with simulated $\left(R_{\mathrm{h}}{ }^{\prime}\right.$, blue $)$ groundwater recharge, and $\mathbf{b}$ estimated $\left(D_{\mathrm{h}}\right.$, grey) with simulated $\left(D_{\mathrm{h}}{ }^{\prime}\right.$, blue $)$ groundwater discharge per day and unit area from the hillslope reservoir during 15 July-31 October 2011 (dashed line) and 15 March-31 October 2012 (continuous line); the first 15 days of each simulation year were neglected; c Time series of estimated $\left(V_{\mathrm{gw}}\right.$, grey) and simulated $\left(V_{\mathrm{gw}}{ }^{\prime}\right.$, blue) groundwater volume; initial values of $V_{\mathrm{gw}}{ }^{\prime}(t)$ were the first observed minimum $V_{\mathrm{gw}}(t)$ for each year ( $t=7$ July 2011 and $t=7$ April 2012, respectively); effective porosity of the aquifer $(\varphi)$ is 0.1

response to smaller rainfall events, however, often exceeded the observations (e.g., July-August 2012). This might be related to the initial values used in Eq. (1) and the assumption of an invariant riparian zone area that omits shrinking and expanding saturated areas during dry and wet periods, respectively (Beven and Kirkby 1979; Dunne and Black 1970).

Still, the applied delineation rule for hydrological landscape units could be verified by fitting the simulation results of 2011 and 2012 to total observed $Q_{\text {e }}$. Presuming a constant event-flow generating area of $25.2 \%$ of $A_{\text {tot }}$, an optimal fit was obtained for $A_{\mathrm{rz}}=8.8 \%$ and $A_{\mathrm{h}}=16.7 \%$, which is in line with the results presented in section "Dominant flow processes and delineation of hydrological landscape units".

\section{Variable contributing areas (VCA)}

The VCA concept was implemented in the minimalistic model through a non-linear relationship between the portion of the riparian zone $\left(A_{\mathrm{rz}}\right)$ and effective precipitation $\left(P_{\mathrm{e}}\right)$. The applied framework is based on the modified SCS-CN equation approach of Dahlke et al. (2009). With this, the area of the riparian zones varied between 0 and $14 \%$ of $A_{\text {tot }}$ during the observation period (Fig. 7c). Detailed calculations of the VCA are shown in section 4 of the ESM.

Hydrogeology Journal (2015) 23: 935-948
The simulated event-flow hydrograph with VCA provides a slightly better fit compared to the CCA appraoch with a smaller deviation to observed $Q_{\mathrm{e}}\left(R^{2}=0.68, p<0.001\right.$, $P_{\text {bias }}=-3.3$, NSE $=0.67$, first month of simulation excluded, Fig. 7b). Since the single-valued indices $R^{2}$ and NSE are generally very sensitive to outliers and sample size (Moriasi et al. 2007), model performance was also evaluated by comparing flow duration curves (fdc) of $Q_{\mathrm{e}}{ }^{\prime}$ with VCA and CCA against observed $Q_{\mathrm{e}}$. Because a fdc captures the entire distribution of event flow rates, a more efficient assessment of model performance is facilitated. Figure $8 \mathrm{a}$ shows that the model with VCA generally captures the event-flow regime better than the model with CCA, i.e., over a wider range of streamflow conditions. For event flow between 0.5 and $3 \mathrm{~mm} \mathrm{~d}^{-1}$ the model with VCA gives similar results as with CCA. The biggest flood events (90th percentile, $Q_{\mathrm{e}}>2.3 \mathrm{~mm} \mathrm{~d}^{-1}$ ), however, are captured more effectively when the model accounts for VCA (inset of Fig. 8a). While the VCA concept provides a good fit during medium and highevent-flow conditions, streamflow responses to short and lowintensity rainfall events with $Q_{\mathrm{e}}<0.3 \mathrm{~mm} \mathrm{~d}^{-1}$ are captured better by the CCA approach (Fig. 8a). This can largely be correlated to the under-prediction of rainfall responses during July-August 2012 (Fig. 7a), which results in a larger offset of the VCA-fdc during the 2012 observation period compared to the previous year (Fig. 8b,c, Fig S6 of the ESM).

Model performances with CCA or VCA are comparable, although median- and peak-flow events were captured 

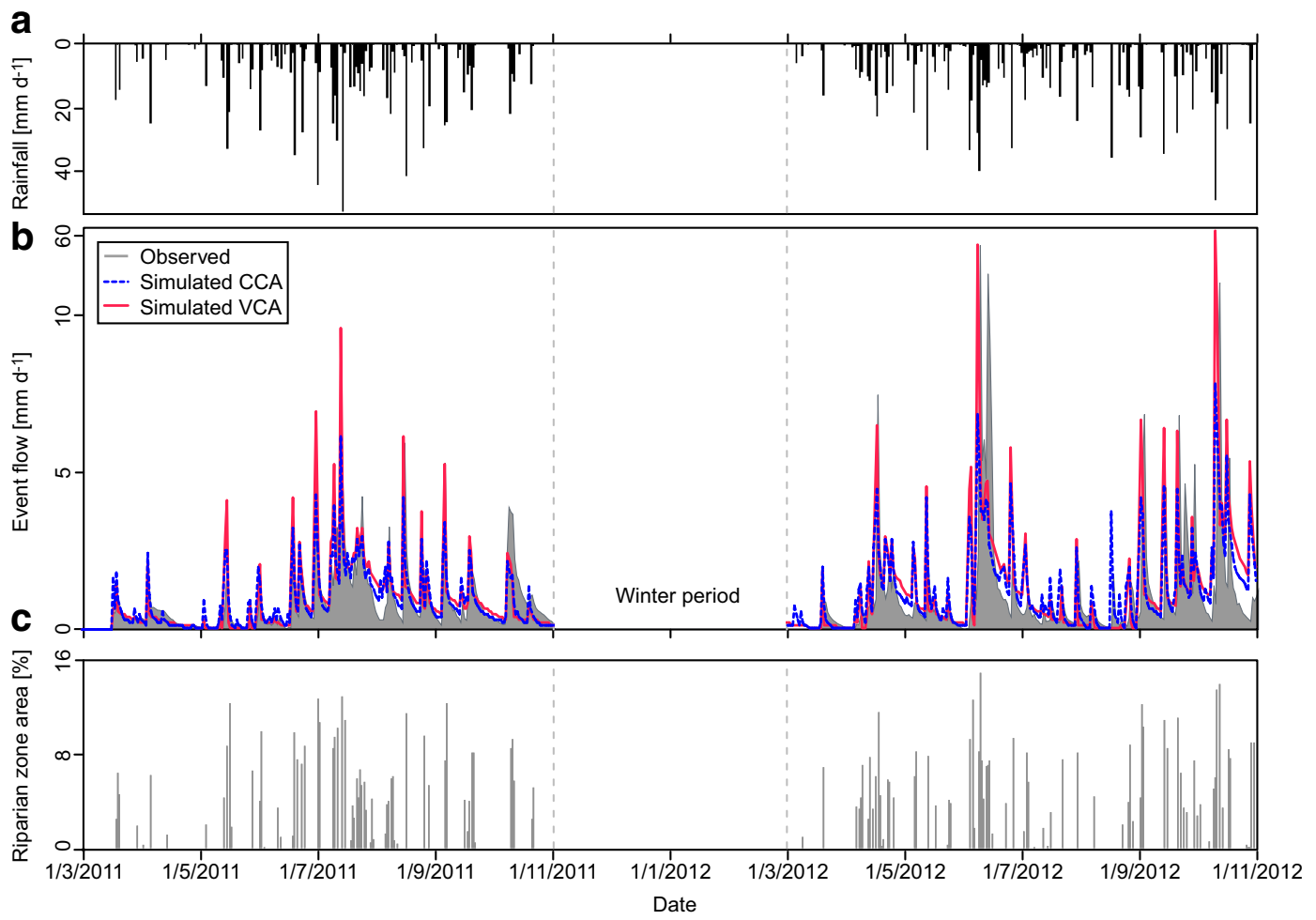

Fig. 7 a Daily rainfall; b Event hydrograph predictions with CCA and VCA: observed event hydrograph (grey shaded areas) and simulated event hydrographs with constant (CCA, blue dashed line) and variable (VCA, red solid line) portions of hydrological landscape during 15 March-31 October 2011 and 15 March-31 October 2012; event flow is streamflow minus baseflow, which was estimated by the recursive filter method of Nathan and McMahon (1990); c Portion of riparian zone relative to the total catchment area

more efficiently when the model accounts for spatial variability of the landscape units. During long and highintensity rainfall events that compensate the soil-water storage deficit in the adjacent lower hillslopes, the riparian zones expand and more shallow subsurface stormflow and surface runoff is generated. Although the absolute range of spatial variability $(0-14 \%)$ is small compared to the total URHB-catchment area, it strongly affects the simulated event-flow hydrograph, particularly during extreme rainfall events. For average flow conditions, however, the areal portions of the landscape units can be considered invariant in time and the minimalistic model with CCA provides a sufficient representation of the event-flow regime of the URHB.

\section{Critical evaluation of the modeling results and implications for the conceptual description of mountainous catchment hydrology}

A minimalistic framework was applied to test whether the hydrological behavior of a mountainous catchment can be explained by the event-flow generation at two landscape units. With only a limited number of parameters and no calibration, the minimalistic model gave robust results with high predictive power. It captured the main hydro (geo) logical dynamics (e.g., timing and amplitude of hillslope groundwater volume, recharge and discharge, event-flow hydrograph) and provided insight on how climate drivers affect hillslope groundwater storage and surface runoff generation at distinct landscape units in a complex environment. In the case of the pre-Alpine URHB, the utilization of such a minimalistic modeling scheme was facilitated by the fact that only a small fraction of the catchment area $(\sim 25 \%)$ actively contributes to event flow. Similar observations were made in other mountainous headwater catchments (e.g., James and Roulet 2009; McGlynn and Seibert 2003; Penna et al. 2011) indicating that a consolidation of a complex landscape into hillslopes and riparian zones might provide a foundation for future studies at larger scales or at other sites. Major limitations of the minimalistic modeling framework that are determined by the initial assumptions, are discussed hereafter and in sections 5 and 6 of the ESM.

\section{Sensitivity analysis}

A qualitative sensitivity analysis of the model key parameters was carried out for both the CCA- and VCAconcept (section 5 of the ESM). It reveals that the soilwater content threshold value $\left(\theta^{*}\right)$ is the most important control on the hydrologic simulations, because it defines the maximum storage deficit in $z_{\mathrm{r}}$, and thus the intensity of groundwater recharge events. The model is less sensitive to the other soil-water storage properties, such as root zone depth $\left(z_{\mathrm{r}}\right)$ and wilting point $\left(\theta_{\mathrm{w}}\right)$, which dominantly control hillslope groundwater contributions to low- and medium flow events. The effects of the groundwater 

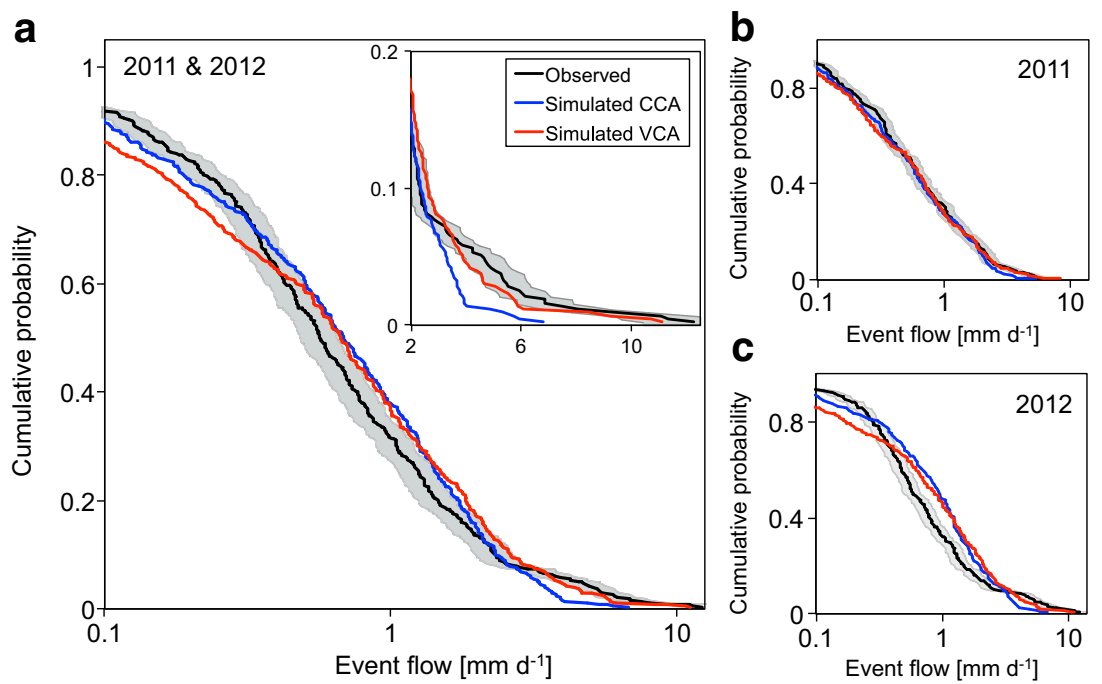

Fig. 8 Comparison of flow duration curves (FDC) of observed (black line with uncertainty bounds of $15 \%$ in grey) and simulated event flow assuming constant contributing areas $(C C A$, blue line) and variable contributing areas ( $V C A$, red line); please note the logarithmic $x$ axis; a Whole observation period (1 March-31 October 2011 and 1 March-31 October 2012), each first month was used as the initialization period in the model and was excluded from the analysis; the inset figure shows the FDC for the upper 20th percentile of event-flow rates (linear $x$-axis); b 2011 observation period; c 2012 observation period

residence time (i.e., groundwater recession constant, $k_{\mathrm{gw}}$ ) are more pronounced towards higher $k_{\mathrm{gw}}$ values since a faster drainage of groundwater from the hillslope reservoir results in an under prediction of event flow.

Overall, the model with CCA shows a smaller sensitivity to the input parameters compared to the VCA-concept, where the shrinking and expanding of the hillslopeand riparian zone areas amplifies parameter-induced model bias.

\section{Total event-flow generating area}

Some of the larger peak flow events were not captured by the minimalistic model, both with the CCA- and VCAconcepts, such as the rainfall events between 31 May-13 June 2012 and 19-27 September 2012 (Fig. 7b). This is probably related to the conceptualization of a total eventflow generating area that comprises $25.2 \%$ of $A_{\text {tot }}$. This may, in turn, limit the maximum areal portions of the hillslopes or riparian zones in the conceptual model.

In order to assess the possible spatial range of the event-flow generating area with respect to the saturated portion $\left(A_{\mathrm{rz}}\right)$, the runoff coefficients $\left(Q_{\mathrm{e}} / P\right)$ for a series of three rainfall events between 31 May and 13 June 2012 were analyzed in detail (section 6 of the ESM). Fitting of $Q_{\mathrm{e}}{ }^{\prime}$ with the areal estimates from section "Simulation of event-flow hydrographs at the catchment scale" (CCA) to observed $Q_{\mathrm{e}}$ reveals that the riparian zone area expanded from around $\sim 5 \%$ and $\sim 7 \%$ during the first two events to $\sim 24 \%$ of $A_{\text {tot }}$ during the last rainfall event (Fig. S6 of the ESM). This value seems reasonable under the assumption that shallow subsurface stormflow in the uppermost hightransmissivity soil zone also occurs on the hillslopes when antecedent soil-water conditions are highest, as was the case during the third event. Similar threshold-like behavior was observed at other experimental hillslopes (e.g.,
Bachmair and Weiler 2011; Dahlke et al. 2012; Lyon et al. 2006). Implementation of this process into the modeling framework would require a variable storage parameter in the modified SCS-SN equation that also accounts for antecedent moisture conditions in the hillslopes (Dahlke et al. 2012). The determination of such a highly non-linear relationship, however, is challenging and would significantly increase model complexity and uncertainty. Still, the minimalistic model with VCA captures the streamflow responses to most of the other high-intensity rainfall events adequately, despite the fact that an invariant event-flow generating area $\left(25.2 \%\right.$ of $\left.A_{\text {tot }}\right)$ and a static storage parameter in the modified SCS-CN equation were presumed (Fig. S6 of the ESM; Fig. 8).

\section{Conclusions}

Prediction of streamflow responses in mountainous headwater catchments requires the identification of characteristic surface and subsurface properties and a holistic understanding of the dominant streamflow-generating mechanisms. Therefore, the present study systematically analyzed landscape features and hydrometric data during the snow-free periods of 2011 and 2012 and applied a minimalistic modeling approach to simulate groundwater dynamics and event-flow generation in a pre-Alpine headwater catchment (URHB). The following dominant landscape units and related hydrological processes can be described:

- The spatial distribution of aquifer geology, slope, soil type and soil depth are the major surface and subsurface properties that determine the spatial extent of the hydrological landscape units where rainfallevent-driven streamflow (event flow) is generated. 
- Deep groundwater discharge (baseflow) originates dominantly from the fractured UFM aquifer, which accounts for $\sim 75 \%$ of the URHB area. The event-flow-generating area comprises the remaining $25 \%$ of the URHB area, whereas riparian zones and adjacent hillslopes cover a real portions of $\sim 8 \%$ and $\sim 17 \%$, respectively.

- During rainfall events, hillslopes dominantly contribute shallow groundwater to the URHB river, while riparian zones generate surface runoff and shallow subsurface stormflow due to a small storage capacity. Streamflow contributions from the riparian zone lead to very short response times of the event-flow hydrograph and is dominant during peak flow.

- A minimalistic threshold-based modeling scheme, that assumes event-flow generation from two linear storage reservoirs with constant contributing areas (CCA), was found to be sufficient to simulate the overall hydrological regime of the URHB.

- The area of the riparian zones expands by up to $14 \%$ when wet antecedent moisture conditions coincide with high-intensity rainfall periods. Consequently, implementation of the variable contributing area concept (VCA) into the minimalistic model improves the overall performance and large flood events can be simulated more effectively.

This study confirms previous observations that stress the important role of landscape properties and variable contributing areas as first-order controls on the hydrological functioning of mountainous headwater catchments. For this, the analysis of groundwater dynamics was shown to facilitate a better understanding of the relationships between climatic drivers (e.g., rainfall, evapotranspiration), subsurface properties and streamflow generation.

Prospective application of this framework could involve the identification of hydrological landscape units that coincide with areas of fertilizer application in agricultural catchments, allowing an efficient assessment of potential source areas of surface water pollution. As shown in the present study, spatiotemporal variability of event-flow-generating areas strongly affects peak flow rates during larger rainfall events due to hydrologically activated hillslopes adjacent to riparian zones. Hence, this process can be expected to exacerbate pollutant export from agricultural areas, where fertilizers and pesticides are applied. Because mountainous catchments serve as vital ecological habitats and important freshwater resources, future work is needed to address these concerns and to evaluate the role of shallow groundwater dynamics and variable contributing areas for the hydrologic and biogeochemical regime in these regions.

Acknowledgements This study was funded by the Swiss National Science Foundation (SNF, Projects No. 200021_129735 and 200020 143688). Additional financial support was provided by the Competence Center Environment and Sustainability (CCES) of the ETH domain in the framework of the RECORD-Assessment and Modeling of Coupled Ecological and Hydrological Dynamics in the Restored Corridor of a River (Restored Corridor Dynamics) - and RECORD Catchment projects. Parts of the data analysis and modeling were completed in collaboration with P.S.C. Rao while the first author (J. v. Freyberg) was at Purdue University, and supported, in part, by the Lee A. Reith Endowment in the Lyle School of Civil Engineering, Purdue University. We would like to thank S. Basso, B. Doulatyari, H. Gall, B. Kianfar, I. Lehner, R. Mégroz, A. Raffainer and C. Wigger for their support during fieldwork and data analysis. The group of S. Seneviratne (LandClimate-Dynamics), Institute for Atmospheric and Climate Science (IAC), Swiss Federal Institute of Technology Zurich (ETHZ) provided data from the meteorological station Büel (lysimeter seepage, rainfall, evapotranspiration) and gauging station Upper Rietholzbach (URHB).

\section{Appendix}

Table 2 Table of abbreviations and model parameters

\begin{tabular}{|c|c|c|c|}
\hline Parameter & Symbol & Unit & $\begin{array}{l}\text { Model input } \\
\text { value }\end{array}$ \\
\hline Soil moisture content & $\theta$ & - & - \\
\hline Soil moisture deficit & $\theta_{\text {def }}$ & - & - \\
\hline Soil moisture threshold & $\theta^{*}$ & - & 0.34 \\
\hline Permanent wilting point & $\theta_{\mathrm{w}}$ & - & 0.17 \\
\hline Aquifer effective porosity & $\varphi$ & - & $0.05-0.1$ \\
\hline Event-flow generating area & $A_{\mathrm{e}}$ & $\%$ & 25.2 \\
\hline $\begin{array}{l}\text { Areal portion of the } \\
\text { hillslopes }\end{array}$ & $A_{\mathrm{h}}$ & $\%$ & $\begin{array}{c}17.7 \text { (CCA), } \\
2.7-17.7 \\
\text { (VCA) }\end{array}$ \\
\hline $\begin{array}{l}\text { Areal portion of the } \\
\text { riparian zones }\end{array}$ & $A_{\mathrm{rz}}$ & $\%$ & $\begin{array}{l}7.5 \text { (CCA), } \\
0-14(\mathrm{VCA})\end{array}$ \\
\hline Total catchment area & $A_{\mathrm{tot}}$ & $\mathrm{L}^{3}$ & $944,049 \mathrm{~m}^{2}$ \\
\hline $\begin{array}{l}\text { Estimated hillslope } \\
\text { groundwater discharge }\end{array}$ & $D_{\mathrm{h}}$ & $\mathrm{L} \mathrm{T}^{-1}$ & - \\
\hline $\begin{array}{l}\text { Simulated hillslope } \\
\text { groundwater discharge }\end{array}$ & $D_{\mathrm{h}}{ }^{\prime}$ & $\mathrm{L} \mathrm{T}^{-1}$ & - \\
\hline Actual evapotranspiration & ET & $\mathrm{L} \mathrm{T}^{-1}$ & - \\
\hline $\begin{array}{l}\text { Hillslope groundwater } \\
\text { recession constant }\end{array}$ & $k_{\mathrm{gw}}$ & $\mathrm{T}^{-1}$ & $0.09 \mathrm{~d}^{-1}$ \\
\hline Depth to water table & $z_{\mathrm{gW}}$ & & - \\
\hline Rainfall & $P$ & $\mathrm{~L} \mathrm{~T}^{-1}$ & - \\
\hline Effective rainfall & $P_{\mathrm{e}}$ & & - \\
\hline $\begin{array}{l}\text { Event flow (streamflow } \\
\text { minus baseflow) }\end{array}$ & $Q_{\mathrm{e}}$ & $\mathrm{L} \mathrm{T}^{-1}$ & - \\
\hline Simulated event flow & $Q_{\mathrm{e}}^{\prime}$ & $\mathrm{L} \mathrm{T}^{-1}$ & - \\
\hline $\begin{array}{l}\text { Total URHB-river } \\
\text { streamflow }\end{array}$ & $Q$ & $\mathrm{~L} \mathrm{~T}^{-1}$ & - \\
\hline $\begin{array}{l}\text { Estimated hillslope } \\
\text { groundwater recharge }\end{array}$ & $R_{\mathrm{h}}$ & $\mathrm{L} \mathrm{T}^{-1}$ & - \\
\hline $\begin{array}{l}\text { Simulated hillslope } \\
\text { groundwater recharge }\end{array}$ & $R_{\mathrm{h}}^{\prime}$ & $\mathrm{L} \mathrm{T}^{-1}$ & - \\
\hline $\begin{array}{l}\text { Estimated hillslope } \\
\text { groundwater volume }\end{array}$ & $V_{\mathrm{gw}}$ & $\mathrm{L}^{3} \mathrm{~T}^{-1}$ & - \\
\hline $\begin{array}{l}\text { Simulated hillslope } \\
\text { groundwater volume }\end{array}$ & $V_{\mathrm{gw}}{ }^{\prime}$ & $\mathrm{L}^{3} \mathrm{~T}^{-1}$ & - \\
\hline Depth to confining layer & $z_{\text {conf }}$ & $\mathrm{L}$ & - \\
\hline Depth of active soil layer & $z_{\mathrm{r}}$ & $\mathrm{L}$ & $300 \mathrm{~mm}$ \\
\hline
\end{tabular}


Ali G, Oswald CJ, Spence C, Cammeraat ELH, McGuire KJ, Meixner T, Reaney SM (2013) Towards a unified thresholdbased hydrological theory: necessary components and recurring challenges. Hydrol Process 27:313-318. doi:10.1002/hyp.9560

Bachmair S, Weiler M (2011) New dimensions of hillslope hydrology. In: Levia DF, Carlyle-Moses D, Tanaka T (eds) Forest hydrology and biogeochemistry, synthesis of past research and future directions, ecological studies, vol 216. Springer, The Netherlands

Balderer W (1984) Hydrogeologie des Murgtales (Kt. Thurgau) [Hydrology of the Murg valley (Canton Thurgau)]. PhD Thesis, University of Neuchâtel, Switzerland, 969 pp

Balderer W (1983) Hydrogeologie der Oberen Süßwassermolasse im Einzugsgebiet des Aubaches (Schweiz) [Hydrogeology of the Upper Freshwater Molasse in the Aubach catchment (Switzerland)]. Steirische Beitr Hydrogeol 34(35):15-54

Balderer W (1984) Hydrogeologische Gesamtsysteme in quartären Lockergesteinsablagerungen [Hydrogeological systems in Quaternary unconsolidated deposits]. Steirische Beitr Hydrogeol $36: 115-125$

Basu NB, Rao PSC, Winzeler HE, Kumar S, Owens P, Merwade V (2010) Parsimonious modeling of hydrologic responses in engineered watersheds: structural heterogeneity versus functional homogeneity. Water Resour Res 46, W04501. doi:10.1029/ 2009wr007803

Beven K (2001) How far can we go in distributed hydrological modelling? Hydrol Earth Syst Sci 5:1-12

Beven K, Kirkby MJ (1979) A physically based, variable contributing area model of basin hydrology. Hydrol Sci Bull 24:43-69

Blöschl G (2011) Scaling and regionalization in hydrology. In: Wilderer P (ed) Treatise on water science. Elsevier, Amsterdam, pp 215-236

Botter G, Porporato A, Rodriguez-Iturbe I, Rinaldo A (2007) Basinscale soil moisture dynamics and the probabilistic characterization of carrier hydrologic flows: slow, leaching-prone components of the hydrologic response. Water Resour Res 43, W02417. doi:10.1029/2006wr005043

Bouwer H, Rice RC (1976) A slug test method for determining hydraulic conductivity of unconfined aquifers with completely or partially penetrating wells. Water Resour Res 12:423-428. doi:10.1029/WR012i003p00423

Brutsaert W (2005) Hydrology: an introduction. Cambrige University Press, New York

Carey SK, Tetzlaff D, Seibert J, Soulsby C, Buttle J, Laudon H, McDonnell J, McGuire K, Cassie D, Shanley J, Kennedy M, Devito K, Pomeroy JW (2010) Inter-comparison of hydroclimatic regimes across northern catchments: synchronicity, resistance and resilience. Hydrol Process 24:3591-3602. doi:10.1002/hyp.7880

Dahlke HE, Easton ZM, Fuka DR, Lyon SW, Steenhuis TS (2009) Modelling variable source area dynamics in a CEAP watershed. Ecohydrology 2:337-349. doi:10.1002/Eco.58

Dahlke HE, Easton ZM, Walter MT, Steenhuis TS (2012) Field test of the variable source area interpretation of the curve number rainfall-runoff equation. J Irrig Drain Eng 138:235-244. doi:10.1061/(Asce)Ir.1943-4774.0000380

Dingman SL (2002) Physical hydrology, 2nd edn. Prentice Hall, Upper Saddle River, NJ

Doppler T, Camenzuli L, Hirzel G, Krauss M, Luck A, Stamm C (2012) Spatial variability of herbicide mobilisation and transport at catchment scale: insights from a field experiment. Hydrol Earth Syst Sci 16:1947-1967. doi:10.5194/Hess-16-1947-2012

Dunne T, Black RD (1970) Partial area contributions to storm runoff in a small New-England watershed. Water Resour Res 6:12961311. doi:10.1029/Wr006i005p01296

Ewen T, Lehner I, Seibert J, Seneviratne SI (2011) Climate patterns in the long-term hydrometeorological data series of the Rietholzbach catchment. Bodenkultur 62:53-58

Gall HE (2013) Landscape filtering of hydrologic and biogeochemical responses in managed catchments. Landsc Ecol 28:651664. doi:10.1007/S10980-012-9829-X
Gburek WJ, Drungil CC, Srinivasan MS, Needelman BA, Woodward DE (2002) Variable-source-area controls on phosphorus transport: bridging the gap between research and design. J Soil Water Conserv 57:534-543

Germann PF (1981) Untersuchungen über den Bodenwasserhaushalt im hydrologischen Einzugsgebiet Rietholzbach [Studies on the soil water balance in the Rietholzbach catchment]. Mitteilungen der Versuchsanstalt für Wasserbau, Hydrologie und Glaziologie der ETH, Zürich, 51 pp

Gharari S, Hrachowitz M, Fenicia F, Savenije HHG (2011) Hydrological landscape classification: investigating the performance of HAND based landscape classifications in a central European meso-scale catchment. Hydrol Earth Syst Sci 15:3275-3291. doi:10.5194/Hess-15-3275-2011

Ghasemizade M, Schirmer M (2013) Subsurface flow contribution in the hydrological cycle: lessons learned and challenges ahead-a review. Environ Earth Sci 69:707-718. doi:10.1007/ S12665-013-2329-8

Graham CB, Woods RA, McDonnell JJ (2010) Hillslope threshold response to rainfall: (1) a field based forensic approach. J Hydrol 393:65-76. doi:10.1016/J.Jhydrol.2009.12.015

Gupta VK, Waymire E, Wang CT (1980) A representation of an instantaneous unit-hydrograph from geomorphology. Water Resour Res 16:855-862. doi:10.1029/Wr016i005p00855

Gurtz J, Verbunt M, Zappa M, Moesch M, Pos F, Moser U (2003a) Long-term hydrometeorological measurements and modelbased analyses in the hydrological research catchment Rietholzbach. J Hydrol Hydromechan 51:162-174

Gurtz J, Zappa M, Jasper K, Lang H, Verbunt M, Badoux A, Vitvar $\mathrm{T}$ (2003b) A comparative study in modelling runoff and its components in two mountainous catchments. Hydrol Process 17:297-311. doi:10.1002/hyp.1125

Healy RW, Scanlon BR (2010) Estimating groundwater recharge. Cambridge University Press, Cambridge

Heidbüchel I, Troch PA, Lyon SW, Weiler M (2012) The master transit time distribution of variable flow systems. Water Resour Res 48. doi:10.1029/2011wr011293

James AL, Roulet NT (2009) Antecedent moisture conditions and catchment morphology as controls on spatial patterns of runoff generation in small forest catchments. J Hydrol 377:351-366. doi:10.1016/j.jhydrol.2009.08.039

Jaun S (2003) Evapotranspiration und Strahlungskomponenten im Forschungsgebiet Rietholzbach [Evapotranspiration and radiation in the Rietholzbach research catchment]. Diploma Thesis, Swiss Federal Institute of Technology Zurich (ETH), Zurich, Switzerland

Kirchner JW (2003) A double paradox in catchment hydrology and geochemistry. Hydrol Process 17:871-874. doi:10.1002/ Hyp. 5108

Koenig P, Lang H, Schwarze R (1994) On the runoff formation in the small pre-alpine research basin Rietholzbach FRIEND: flow regimes from International Experimental and Network Data (Proceedings of the Braunschweig Conference, October 1993) IAHS Publ. no. 221, IAHS, Wallingford, UK, pp 391-398

Lyon SW, McHale MR, Walter MT, Steenhuis TS (2006) The impact of runoff generation mechanisms on the location of critical source areas. J Am Water Resour Assoc 42:793-804. doi:10.1111/J.1752-1688.2006.Tb04493.X

Martina MLV, Entekhabi D (2006) Identification of runoff generation spatial distribution using conventional hydrologic gauge time series. Water Resour Res 42, W08431. doi:10.1029/ 2005wr004783

McGlynn BL, Seibert J (2003) Distributed assessment of contributing area and riparian buffering along stream networks. Water Resour Res 39:1082. doi:10.1029/2002wr001521

McGlynn BL, McDonnell JJ, Seibert J, Kendall C (2004) Scale effects on headwater catchment runoff timing, flow sources, and groundwater-streamflow relations. Water Resour Res 40. doi:10.1029/2003wr002494

McGrath GS, Hinz C, Sivapalan M (2007) Temporal dynamics of hydrological threshold events. Hydrol Earth Syst Sci 11:923938 
MeteoSchweiz (2013) Klimaszenarien Schweiz-eine regionale Übersicht. Fachbericht MeteoSchweiz Nr 243. [Climate scenarios of Switzerland-a regional overview. Technical Report MeteoSwiss No 243]. Swiss Federal Office for the Environment (FOEN), Bern, Switzerland, $36 \mathrm{pp}$

Mittelbach H, Lehner I, Seneviratne SI (2012) Comparison of four soil moisture sensor types under field conditions in Switzerland. J Hydrol 430:39-49. doi:10.1016/J.Jhydrol.2012.01.041

Moriasi DN, Arnold JG, Van Liew MW, Bingner RL, Harmel RD, Veith TL (2007) Model evaluation guidelines for systematic quantification of accuracy in watershed simulations. Trans ASABE 50:885-900

Nathan RJ, McMahon TA (1990) Evaluation of automated techniques for base-flow and recession analyses. Water Resour Res 26:1465-1473. doi:10.1029/Wr026i007p01465

Penna D, Tromp-van Meerveld HJ, Gobbi A, Borga M, Dalla Fontana G (2011) The influence of soil moisture on threshold runoff generation processes in an alpine headwater catchment. Hydrol Earth Syst Sci 15:689-702. doi:10.5194/hess-15-6892011

Philip JR (1957) The theory of infiltration: 4. sorptivity and algebraic infiltration equations. Soil Sci 84:257-264

Posavec K, Parlov J, Nakic Z (2010) Fully automated objectivebased method for master recession curve separation. Ground Water 48:598-603. doi:10.1111/J.1745-6584.2009.00669.X

Rinaldo A, Beven KJ, Bertuzzo E, Nicotina L, Davies J, Fiori A, Russo D, Botter G (2011) Catchment travel time distributions and water flow in soils. Water Resour Res 47, W07537. doi:10.1029/2011wr010478

Rodriguez-Iturbe I, Porporato A, Ridolfi L, Isham V, Cox DR (1999) Probabilistic modelling of water balance at a point: the role of climate, soil and vegetation. Proc Roy Soc A Math Phys 455:3789-3805

Seibert J, McGlynn BL (2005) Landscape element contributions to storm runoff. In: Anderson MG, McDonnell G (ed) Encyclopedia of hydrological sciences. pp 1751-1761

Seneviratne SI, Lehner I, Gurtz J, Teuling AJ, Lang H, Moser U, Grebner D, Menzel L, Schroff K, Vitvar T, Zappa M (2012)
Swiss prealpine Rietholzbach research catchment and lysimeter: 32 year time series and 2003 drought event. Water Resour Res 48, W06526. doi:10.1029/2011wr011749

Sivapalan M (2003) Process complexity at hillslope scale, process simplicity at the watershed scale: is there a connection? Hydrol Process 17:1037-1041. doi:10.1002/Hyp.5109

Tetzlaff D, Soulsby C, Bacon PJ, Youngson AF, Gibbins C, Malcolm IA (2007) Connectivity between landscapes and riverscapes: a unifying theme in integrating hydrology and ecology in catchment science? Hydrol Process 21:1385-1389. doi:10.1002/hyp.6701

Teuling AJ, Lehner I, Kirchner JW, Seneviratne SI (2010) Catchments as simple dynamical systems: experience from a Swiss prealpine catchment. Water Resour Res 46, W10502. doi:10.1029/2009wr008777

Thompson SE, Basu NB, Lascurain J, Aubeneau A, Rao PSC (2011) Relative dominance of hydrologic versus biogeochemical factors on solute export across impact gradients. Water Resour Res 47, W00J05. doi:10.1029/2010wr009605

Vitvar T, Balderer W (1997) Estimation of mean water residence times and runoff generation by O-18 measurements in a preAlpine catchment (Rietholzbach, eastern Switzerland). Appl Geochem 12:787-796. doi:10.1016/S0883-2927(97)00045-0

Viviroli D, Weingartner R, Messerli B (2003) Assessing the hydrological significance of the world's mountains. Mt Res D e v $23: 32-40$. d o i : $10.1659 / 0276$ 4741(2003)023[0032:Athsot]2.0.Co;2

von Freyberg J, Radny D, Gall HE, Schirmer M (2014) Implications of hydrologic connectivity between hillslopes and riparian zones on streamflow composition. J Contam Hydrol 169:6274. doi:10.1016/j.jconhyd.2014.07.005

Woodbury JD, Shoemaker CA, Easton ZM, Cowan DM (2014) Application of SWAT with and without variable source area hydrology to a large watershed. J Am Water Resour Assoc 50:42-56. doi:10.1111/Jawr.12116

Zehe E, Sivapalan M (2009) Threshold behaviour in hydrological systems as (human) geo-ecosystems: manifestations, controls, implications. Hydrol Earth Syst Sci 13:1273-1297 